[Agr. Biol. Chem., Vol. 36, No. 4, p. 684 689, 1972]

\title{
Electrophoretic Studies of Alkaline Proteinases from Strains of Aspergillus flavus Group
}

\author{
By Seiichi Nasuno \\ Noda Institute for Scientific Research, Noda-shi, Chiba-ken \\ Received October 18, 1971
}

A large number of papers have been published on the taxonomy of Aspergilli during the last few decades. As one of the results of such efforts, new publication of "The Genus Aspergillus" by Raper and Fennell" was emerged from "A Manual of the Aspergilli" by Thom and Raper." In addition to this, Murakami ${ }^{3 !}$ recently completed the classification of Japanese industrial strains of yellow-green Aspergilli and related fungi with the aid of multi-component analysis after laborious and extensive studies for more than ten years. However, as far as the classification of strains of Aspergillus flavus group (based on the description by Raper and Fennell in this report) is concerned, there are still some questions on the definition of fungal taxa. Since no true sexual life cycle has been found in any strains of this group, species concept is ambiguous and creation of the species is rather arbitrary.

In a previous paper ${ }^{4}$ the author found that alkaline proteinases from most of the Aspergillus species showed species-specific mobility in electrophoresis on acrylamide gel columns. Therefore, application of this technique to the species of a certain group was expected to give some clues to support the established classification of imperfect fungi and to provide evidence at molecular level on establishment of some species in that group. For example, although $A$. sojae was distinguished from $A$. oryzae by Sakaguchi and Yamada ${ }^{5}$ in 1944 on the basis of the nature of conidia walls, this separation was recently confirmed to be reasonable by the electrophoretic studies of al- kaline proteinases produced by these species." The aim of this note is to report the results of the similar experiments relevent to the taxonomy and phylogeny of the strains in $A$. flavus group.

Fungal strains were kindly supplied by Dr. H. Murakami, Research Institute of Brewing, Tokyo (RIB) and Culture Collection of the Institute of Applied Microbiology, University of Tokyo (IAM). In this paper $A$. sojae and $A$. toxicarius were respectively separated from $A$. oryzae and $A$. flavus according to the classification by Sakaguchi and Yamada ${ }^{5}$ and Murakami. ${ }^{31}$

Samples for gel electrophoresis were prepared by the method in the previous paper. ${ }^{4}$ Alkaline proteinases, much or less, were produced on wheat bran solid culture for 72 to $120 \mathrm{hr}$ by all the strains examined but $A$. zonatus RIB 1033 which did not form the proteinase under various cultural conditions. Polyacrylamide gel electrophoresis was accomplished by the method of Davis ${ }^{6}$ for $\mathrm{pH} 9.4$ gels and of Reisfeld et al. ${ }^{71}$ for $\mathrm{pH} 4.0$ gels. After a run at $4 \mathrm{~mA}$ per gel column at $4^{\circ} \mathrm{C}$ for $90 \mathrm{~min}(\mathrm{pH} 9.4$ gels) or $180 \mathrm{~min}(\mathrm{pH} 4.0$ gels), gels were fractionated in $2 \mathrm{~mm}$ thick with a gel slicer and extracted overnight with $2 \mathrm{ml}$ of $0.05 \mathrm{M}$ phosphate buffer $(\mathrm{pH} 7.3)$ at $4^{\circ} \mathrm{C}$. The enzyme activities of the fractionated gels were assayed by the method previously reported, ${ }^{8}$ but expressed as arbitrary units.

Electron micrographs of dry conidia on Formvar-coated grids were taken with a JEM7A type electron microscope. Mature conidia 


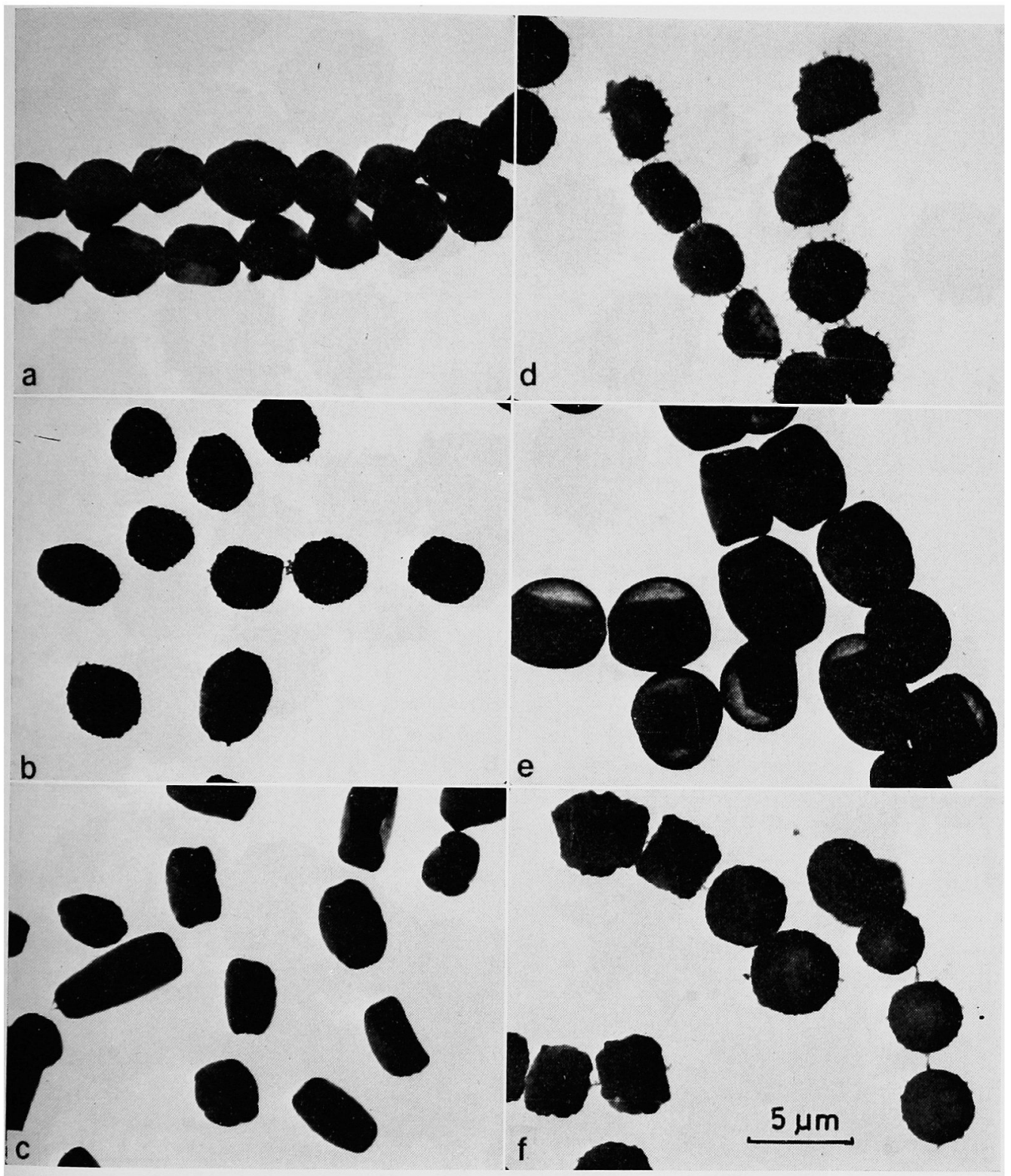

FIG. 1. Electron Micrographs of Smooth or Roughened Conidia of Some Strains in Aspergillus flavus Group.

(a) A. oryzae RIB 81, (b) A. zonatus RIB 1033, (c) A. clavato-flavus RIB 1034, (d) A. subolivaceus RIB 1035, (e) A. avenaceus RIB 1036, (f) A. flavus RIB 1406. (×3,000).

for this purpose were obtained by incubation of fungi on Czapek's solution agar slants at $30^{\circ} \mathrm{C}$ for 3 weeks.
Figures 1 and 2 were the electron micrographs of conidia of the strains used. $A$. oryzae, A. zonatus, A. clavato-flavus, A. suboli- 


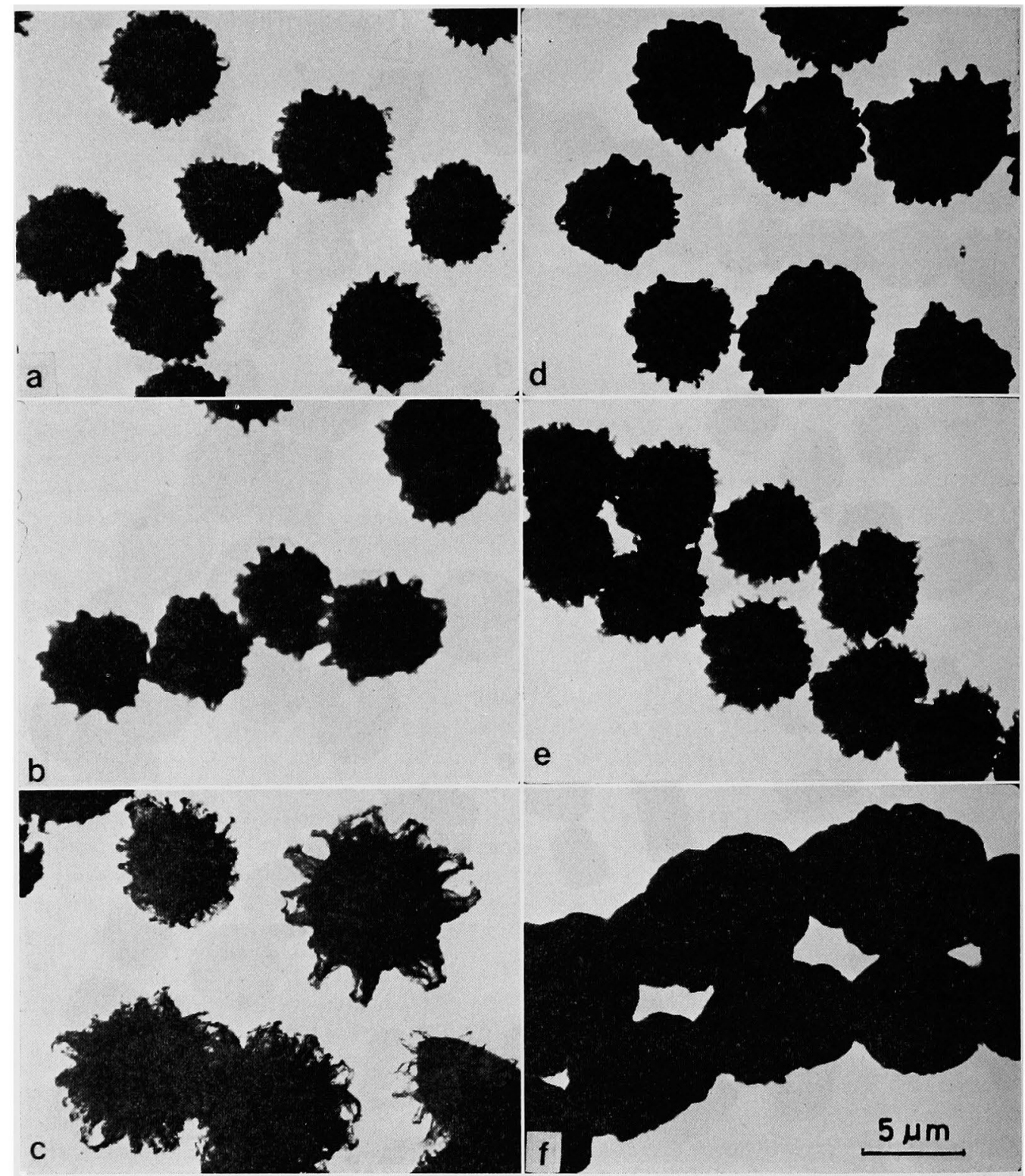

FIG. 2. Electron Micrographs of Echinulate or Tuberculate Conidia of Some Strains in Aspergillus flavus Group.

(a) A. sojae RIB 401, (b) A. sojae RIB 405, (c) A.tamarii IAM 2499, (d) A. parasiticus RIB 4032, (e) A. toxicarius RIB 4001, (f) A. flavo-furcatis RIB 3006. $(\times 3,000)$.

vaceus, $A$. avenaceus, and $A$. flavus showed the and A. flavo-furcatis exhibited echinulate or smooth or somewhat roughened conidia, but tuberculate conidia. As described later, the A. sojae, A. parasiticus, A. toxicarius, A. tamarii, nature of conidia walls highly correlated with 


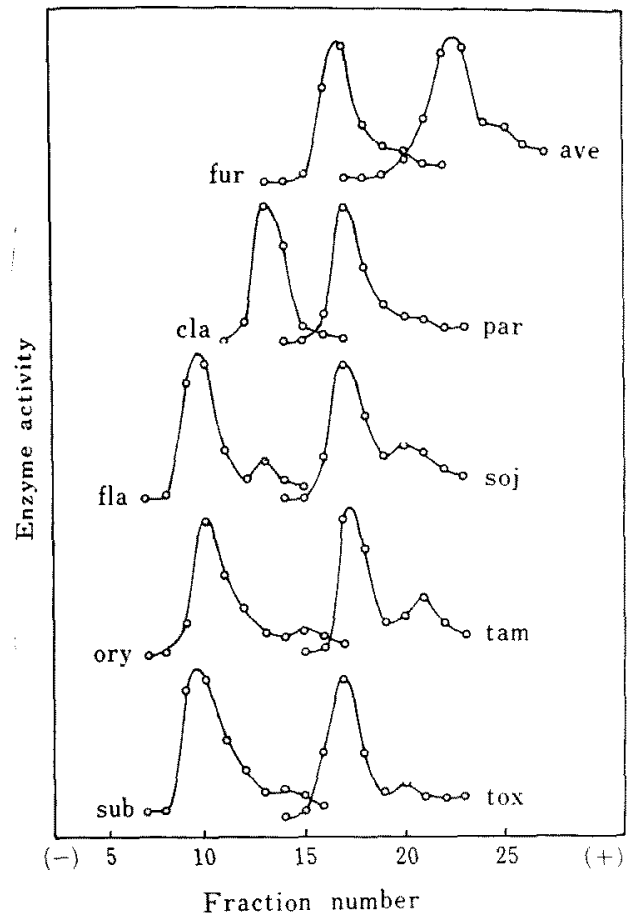

FIg. 3. Electrophoregrams of Alkaline Proteinases from Strains of Aspergillus flavus Group on Polyacrylamide Gel Columns at pH 9.4 for $90 \mathrm{~min}$.

Strains: fur $=$ A. flavo-furcatis, ave $=A$. avenaceus, $\mathrm{cla}=A$. clavato-flavus, $\mathrm{par}=A$. parasiticus, $\mathrm{fa}=A$. flavus, soj $=A$. sojae, ory $=A$. oryzae, $\operatorname{tam}=A$. tamarii, sub $=A$. subolivaceus, tox $=A$. toxicarius.

the electrophoretic mobilities of alkaline proteinases produced by these species.

Figures 3 and 4 illustrate the electrophoretic patterns of alkaline proteinases formed by the representative strains of $A$. flavus group in polyacrylamide gels at $\mathrm{pH} 9.4$ and $\mathrm{pH} 4.0$, respectively. In either case alkaline proteinases from $A$. flavo-furcatis, $A$. tamarii, $A$. parasiticus, and $A$. toxicarius showed the same electrophoretic mobilities as that from $A$. sojae. It is noteworthy that all these strains produce echinulate or tuberculate conidia (Fig. 2). To the contrary, $A$. flavus and $A$. subolivaceus producing smooth conidia (Fig. 1) secreted alkaline proteinases which have the same

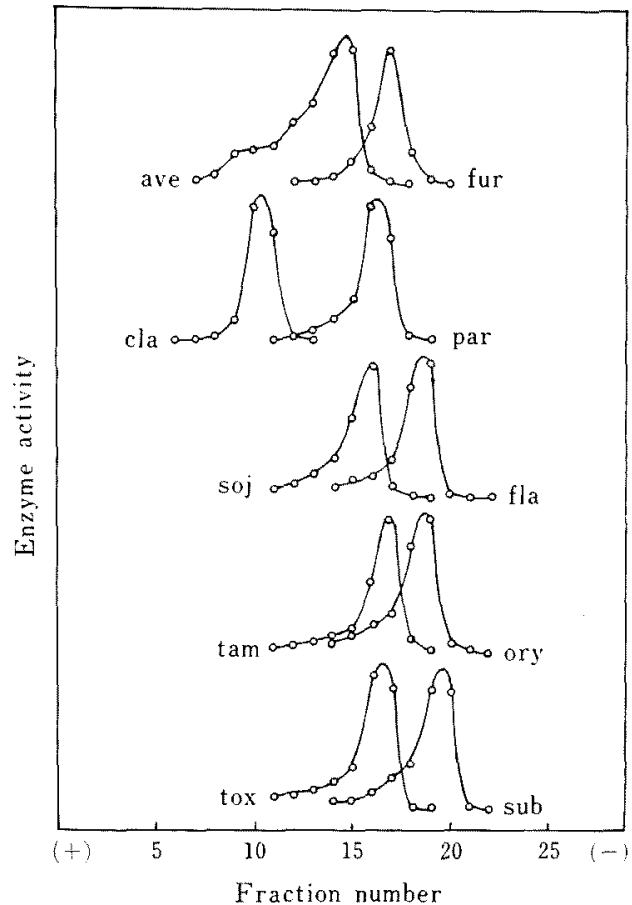

FIG. 4. Polyacrylamide Gel Electrophoresis Patterns of Alkaline Proteinases from Strains of Aspergillus flavus Group at $\mathrm{pH} 4.0$ for $180 \mathrm{~min}$.

Strains: ave $=A$. avenaceus, fur $=A$. flavo-furcatis, cla $=A$. clavato-flavus, $\operatorname{par}=A$, parasiticus, $\quad s 0 \mathrm{j}=A$. sojae, fla $=A$. flavus, tam $=A$. tamarii, ory $=A$. oryzae, tox $=A$. toxicarius, sub $=A$. subolivaceus.

mobilities as the proteinase of $A$. oryzae in polyacrylamide gel electrophoresis under the acid or alkaline condition.

Since the electrophoretic mobility is considered to reflect the net charge, shape, and dimension of the enzyme protein and physicochemical properties of alkaline proteinase from $A$. oryzae are almost the same to those from $A$. flavus, ${ }^{9-13:}$ the enzyme from $A$. subolivaceus seems to be identical or very much homologous to that from $A$. oryzae, although any informations are not yet available about analytical data such as amino acid composition, amino acids at amino- and carboxylterminals, and molecular weight of $A$. suboli- 
vaceus enzyme. Similarly, the enzymes from A. tamarii, A. flavo-furcatis, A. parasiticus, and A. toxicarius may be identical or homologous to that from $A$, sojae.

The electrophoretic mobility of alkaline proteinase from $A$. clavatoflavus was between those from $A$. oryzae and $A$. sojae in $\mathrm{pH} 9.4$ gels and was the smallest of all enzymes examined in $\mathrm{pH} 4.0$ gels. On the other hand, the proteinase from $A$. avenaceus moved fastest at $\mathrm{pH} 9.4$ gels and migrated in the midst of those from $A$. clavato-flavus and $A$. oryzae at $\mathrm{pH} 4.0$ gels. Changes in the order of mobilities of the enzymes from these species in acid and alkaline gels are not strange, since the fact that two proteins possessing identical isoelectric points will not necessarily have identical mobilities throughout the whole $\mathrm{pH}$ range is already known by the mobility-pH curves of purified human serum proteins and of bovine serum albumin. ${ }^{14}$ Therefore, alkaline proteinases of A. flavus group can be electrophoretically classed into 4 types re-

Table 1. The Natures of Conidia Walls and Electrophoretic Types of Alkaline ProteInases Produced by SPECIES OF Aspergillus flavus GROUP

\begin{tabular}{llll}
$\begin{array}{c}\text { Speciesclassed } \\
\text { by Raper }\end{array}$ & $\begin{array}{c}\text { Species } \\
\text { assigned by } \\
\text { Murakamias }\end{array}$ & Conidia & $\begin{array}{c}\text { Alkaline } \\
\text { pro- } \\
\text { teinase }\end{array}$ \\
\hline A. flavus & $\begin{array}{l}\text { A. flavus } \\
\text { A. toxicarius }\end{array}$ & $\begin{array}{l}\text { smooth } \\
\text { echinulate }\end{array}$ & $\begin{array}{c}\text { ory } \\
\text { soj }\end{array}$ \\
A. parasiticus & A. parasiticus & echinulate & soj \\
A. oryzae & A. oryzae & smooth & ory \\
& A. sojae & echinulate & soj \\
A. zonatus & (A. flavus) & smooth & - \\
A. clavato-flavus & (A. oryzae) & smooth & cla \\
A. tamarii & A. tamarii & tuberculate & soj \\
A. flavo-furcatis & (A. tamarii) & tuberculate & soj \\
A. subolivaceus & (A. flavus) & smooth & ory \\
A. avenaceus & (A. flavus) & smooth & ave \\
\hline
\end{tabular}

a) The species described by Raper \& Fennell are very close to the species in parentheses according to the classification by Murakami.

b) ory $=A$. oryzae type, $s o j=A$. sojae type, cla $=$ A. clavato-flavus type, ave $=A$. avenaceus type. presented by the enzymes from $A$. oryzae, $A$. sojae, A. clavato-flavus, and $A$. avenaceus (Table I).

The results of multi-component analyses of the morphological and physiological characters of a number of strains in $A$. flavus group by Murakami $^{15)}$ indicate that $A$. clavato-flavus is very close to $A$. oryzae and that $A$. zonatus, A. subolivaceus, and $A$. avenaceus are close to A. flavus. However, the electrophoretic studies on alkaline proteinases produced by these strains apparently differentiated $A$. clavatoflavus and $A$. avenaceus from other species. The electrophoretic classification again supported the rationality of the separation of A. toxicarius from A. flavus based on the properties of conidial surfaces by Murakami. ${ }^{31}$

Moreover, the above results suggest some phylogenetic relationship among the species in A. flavus group. The species producing the proteinases with the same electrophoretic mobilities may be phylogenetically closer each other than other species producing the proteinases with different mobilities in this group, although more analytical data are necessary to establish this speculation.

Acknowledgements. The author is grateful to Dr. H. Murakami, Research Institute of Brewing, Profs. $Y$. Ikeda and $K$. Arima, University of Tokyo for their valuable suggestions and discussions. The author wishes to thank Drs. M. Mogi and N. Iguchi for encouragement and Miss Y. Endo for technical assistance.

\section{REFERENCES}

1) K. B. Raper and D. I. Fennell, "The Genus Aspergillus," The Williams \& Wilkins Co., Baltimore, 1965.

2) C. Thom and K. B. Raper, "A Manual of the Aspergilli, The Williams \& Wilkins Co., Baltimore, 1945.

3) H. Murakami, J. Gen. Appl. Microbiol, in press.

4) S. Nasuno, Agr. Biol. Chem., 35, 1147 (1971).

5) K. Sakaguchi and K. Yamada, Nippon Nogeikagaku Kaishi, 20, 65, 121 (1944). 
6) B. J. Davis, Ann. N. Y. Acad. Sci., 121, 404 (1964).

7) R. A. Reisfeld, U. J. Lewis and D. E. Williams, Nature, 195, 281 (1962).

8) H. Sekine, S. Nasuno and N. Iguchi, Agr. Biol. Chem., 33, 1477 (1969).

9) A. R. Subramanian and G. Kalnitsky, Biochemisty, 3, 1861 (1964).

10) A. R. Subramanian and G. Kalnitsky, ibid., 3, 1868 (1964).

11) A. Nordwig and W. F. Jahn, Europ. J. Biochem.,
3, $519(1968)$.

12) J. Turková, O. Mikeš, K. Gančev and M. Boublik, Biochem. Biophys. Acta, 178, 100 (1969).

13) O. Mikeš, J. Turková, N. B. Toan and F. Sorm, ibid, 178, 112 (1969).

14) G. Zweig and J. R. Whitaker, "Paper Chromatography and Electrophoresis," Vol. I, Academic Press Inc., New York, 1967, p. 102.

15) H. Murakami, Rept. Inst. Brewing, Japan, No. $142,32(1970)$. 